\title{
Technique of Granulation Tissue Genesis from Diploe
}

\author{
Essossinam Kpelao1*, Moumouni Abd El Kader'1, Beketi Kadanga Anthony ${ }^{1}$, Amouzou Alain', \\ Doleagbenou Agbeko', Ahanogbe Hobli' ${ }^{1}$, Egu Komi1', Bakonde Essolim¹, Abalo Anani³
}

${ }^{1}$ Department of Neurosurgery, Sylvanus Olympio University Hospital, Lomé, Togo

${ }^{2}$ Department of Plastic and Reconstructive Surgery, Sylvanus Olympio University Hospital, Lomé, Togo

${ }^{3}$ Department of Traumatology and Orthopedics, Sylvanus Olympio University Hospital, Lomé, Togo

Email: *kpelas77@yahoo.fr

How to cite this paper: Kpelao, E., Abd El Kader, M., Anthony, B.K., Alain, A., Agbeko, D., Hobli, A., Komi, E., Essolim, B. and Anani, A. (2018) Technique of Granulation Tissue Genesis from Diploe. Modern Plastic Surgery, 8, 9-14.

https://doi.org/10.4236/mps.2018.82002

Received: January 11, 2018

Accepted: February 10, 2018

Published: February 13, 2018

Copyright $\odot 2018$ by authors and Scientific Research Publishing Inc. This work is licensed under the Creative Commons Attribution International License (CC BY 4.0).

http://creativecommons.org/licenses/by/4.0/

\begin{abstract}
Introduction: Many techniques are used in surgery for importing scalp losses. Microsurgery reinsertion dominates these techniques. When reinsertion is not possible, other alternatives are available. Among these is the production of the granulation tissue by diploic perforation. Many authors have reported this technic without explaining the physiological mechanisms that contribute to the genesis of this granulation tissue from the diploe. We intend to recall them. Patients and Methods: This was a series of 3 cases supported for significant loss of the scalp. The technic consisted in making trepan drill holes and carrying the outer table to the diploe by using a Doyen drill. Then fat dressings were applied every other day until the formation of granulation tissue over the entire loss of tissue surface. Observations: Three patients benefited from this technique, 2 traumatic and the other one iatrogenic after a scalp tumor excision. The missing area of traumatic wounds was estimated at 18 and $25 \mathrm{~cm}^{2}$ respectively. The third patient had a loss of scalp after surgical removal of an ulcerous-budding tumor of the scalp without any impacting the skull. Granulation tissue was obtained in all cases after an average of 30 days. There was no infection. Two patients were grafted with favorable progress and one patient went under indirect wound healing. Conclusion: The ability of the diploe to generate granulation tissue is due to its intrinsic anatomical and functional potentialities. This is a technic of last resort when conventional reconstructive surgery is contraindicated for several reasons.
\end{abstract}

\section{Keywords}

Granulation Tissue, Diploe

\section{Introduction}

The scalp is the skin on the head that grows the hair. Adult scalp has a surface 
area of about $800 \mathrm{~cm}^{2}$, representing $5 \%$ of the total body surface area with a thickness of about $6 \mathrm{~mm}$. Many technics apply to surgery of the scalp when there is large loss of tissue. Scalp reinsertion microsurgery dominates all scalp surgery techniques in cases of total avulsion [1] [2]. When reinsertion is not possible for several reasons [1], other alternatives are available depending on whether the pericranium is intact or not [3] [4] [5]. Among these, the production of the granulating tissue by diploic perforation, as a base for a skin graft can be use [6] [7] [8]. It is an old technic, often unknown to neurosurgeons, who are sometimes confronted with the lack of closure, especially in scalp tumor excision. Many authors have reported this technic without explaining the physiological mechanisms that contribute to the genesis of this granulating tissue from the diploe. We intend to recall them through this study.

\section{Patients and Methods}

This was a series of 3 cases that has gone under care for significant loss of scalp tissue. The technic consisted in making trepan drill holes and carrying the outer table to the diploe by using a Doyen drill (Figure 1). Then fat dressings were applied every other day until the formation of granulating tissue over the entire loss of tissue surface (Figure 2). The third step was to make skin grafts.

\section{Result}

Three patients of two women and one man had gone under care in the neurological and surgical department for significant loss of scalp tissue, 2 from traumatic origin and the other one iatrogenic after a scalp tumor excision. The two traumatic wounds were readmitted in ower department after an initial management in a remote hospital respectively after one and two weeks of the trauma. This was a secondary necrosis of the scalp after debridement. The missing area was estimated at 18 and $25 \mathrm{~cm}^{2}$ respectively. Patients underwent stripping and excision with the periosteum first, followed by a diploic perforation. The third patient benefitted from this technic after surgical removal

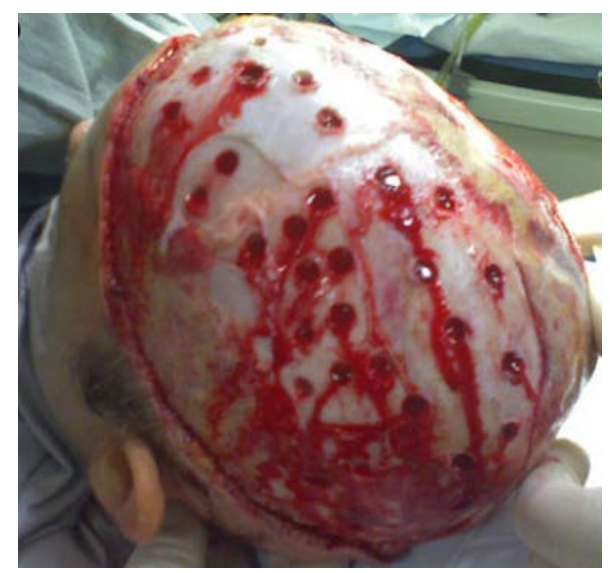

Figure 1. Multiple perforations of the outer table [22]. 


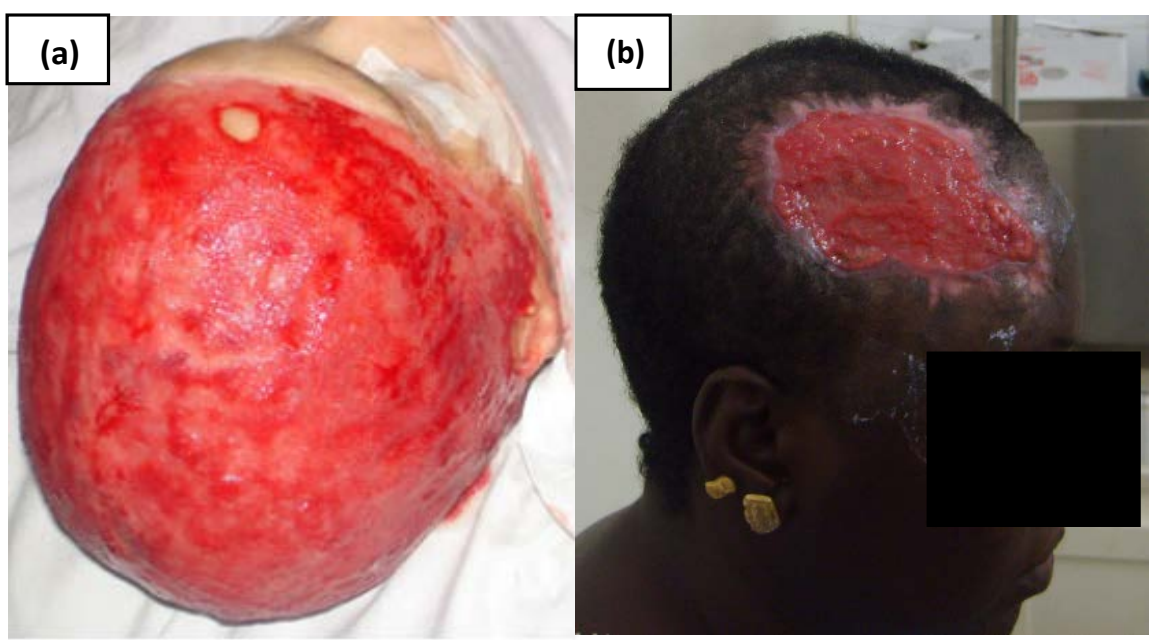

Figure 2. Budding granulation tissue ready for skin grafting (a), (b).

of an ulcerous-budding tumor of the scalp without any impacting the skull. Granulation tissue was obtained in all cases after an average of 30 days (Figure 2). There was no infection. Two patients were grafted with favorable progress and one patient went under indirect wound healing.

\section{Discussion}

The formation of granulating tissue is carried out in 3 successive phases: formation of blood clot, inflammatory reaction and proliferative phase. After a tissue wound, coagulation leads to the formation of a blood fibrino-platelet clot throughout platelets degranulation and aggregation. This clot will constitute a temporary matrix allowing migration of endothelial cells, inflammatory cells and fibroblasts. The growth factors released by platelet degranulation stimulate the angiogenic response. The clot will shrink and the underlying connective tissue is called granulating tissue because of the pink granulations that correspond to the numerous capillaries that invade it [9] [10]. The capacity of the diploe to generating a granulating tissue comes from 2 potentialities: its abundance in blood vessels and stem cells [11]. The diploe contains veins that form blood lakes which are discharged into the cranial sinuses. These diplotic veins are grouped in frontal, anterior temporal, posterior and occipital veins. Their size is inverse to age, almost nil for the fetus, they grow and develop as the bones of the skull become thicker and more completely united [12]. Thus the ablation of the outer table of the skull by perforation or milling gives access to these diploic veins which can directly feed an immediate skin graft on one hand [6]; and on the other hand constitutes a tissue wound in which will trigger the repair process conducting to the formation of granulation tissue [13] [14] [15] (Figure 3). The diploe composed of spongy bones also contains mesenchymal and hematopoietic pluripotent stem cells. These pluripotent cells have the ability to differentiate themselves into many cell types according to site needs and stimuli [14] [15] [16] [17] [18]. Thus, exposing this spongy tissue after ablation of the 


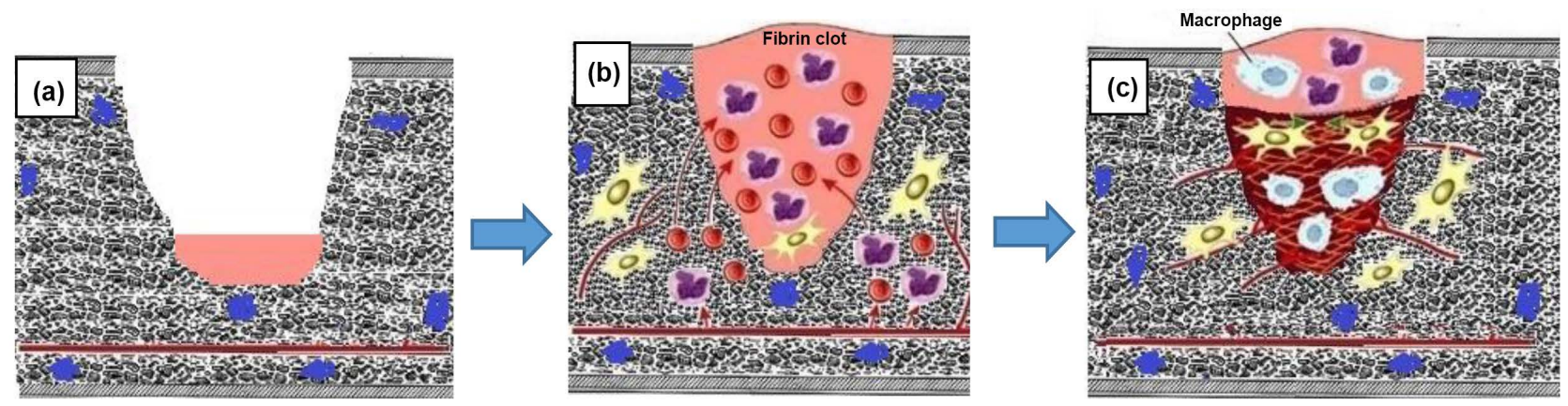

Figure 3. Diagrams illustrating the different stages of formation of the granulation tissue. Perforation of the diploe containing venous lakes (a) which triggers the influx of inflammatory and multipotent cells (b) resulting in the formation of a granulation tissue (c).

external table leads the cell differentiation towards the formation of granulation tissue. This technic requires regular dressing changes to maintain a moist environment [7] [19]. All kind of dressing may be used if only are they occlusive. However, hydrocolloid and impregnated dressings can be used to stimulate the formation of granulation tissue. The VAC system can also be used to shorten delays but has never been attempted on the head. This technic is only recommended in absence of the pericranium because the granulation tissue can also come from the periosteum when it is intact [20]. The principle is not crossing the internal table to limit the infectious and vascular risks. The disadvantage of this technic is the long delay before obtaining granulation tissue which exposes to infections and long term hospitalization [21].

\section{Conclusion}

The ability of the diploe which is a bony structure to generate granulation tissue is due to its intrinsic anatomical and functional potentialities. Budding from the diploe is a simple and historical technic. It is little known to neurosurgeons because of the rarity of complete scalp avulsion. It is used mainly in total avulsion of the scalp, but also in large loss when other technical alternatives are not available. This is a technic of last resort when conventional reconstructive surgery is contraindicated for several reasons.

\section{Patient Consent}

The patients gave consent for the publication of this case;

\section{Conflict of Interest}

All authors declare no conflicting interests and none of them are supported/funded by and drug company.

\section{Ethical Approval}

Approval for the study was obtained from the national medical ethic committee. 


\section{References}

[1] Cheng, K., Zhou, S., Jiang, K., Wang, S., Dong, J., Huang, W. and Chang, T. (1996) Microsurgical Replantation of the Avulsed Scalp: Report of 20 Cases. Plastic and Reconstructive Surgery, 97, 1099-1108. https://doi.org/10.1097/00006534-199605000-00001

[2] Yin, J.W., Matsuo, J.M., Hsieh, C.H., Yeh, M.C., Liao, W.C. and Jeng, S.F. (2008) Replantation of Total Avulsed Scalp with Microsurgery: Experience of Eight Cases and Literature Review. Journal of Trauma and Acute Care Surgery, 64, 796-802. https://doi.org/10.1097/TA.0b013e3180341fdb

[3] Mc Clean, D. and Buncke, H. (1972) Autotransplant of Omentum to a Large Scalp Defect with Microsurgical Revascularization. Plastic and Reconstructive Surgery, 49, 268-274. https://doi.org/10.1097/00006534-197203000-00005

[4] Maxwell, P., Steuber, K. and Hoopes, J. (1978) A Free Latissimus Dorsi Myocutaneous Flap. Plastic and Reconstructive Surgery, 62, 462-466. https://doi.org/10.1097/00006534-197809000-00033

[5] Borah, G.L., Hidalgo, D.A. and Wey, P.D. (1995) Reconstruction of Extensive Scalp Defects with Rectus Free Flaps. Annals of Plastic Surgery, 34, 281.

https://doi.org/10.1097/00000637-199503000-00010

[6] Mühlstädt, M., Thomé, C. and Kunte, C. (2012) Rapid Wound Healing of Scalp Wounds Devoid of Periosteum with Milling of the Outer Table and Split-Thickness Skin Grafting. British Journal of Dermatology, 167, 343-347. https://doi.org/10.1111/j.1365-2133.2012.10999.x

[7] Latenser, J., Snow, S.N., Mohs, F.E., et al. (1991) Power Drills to Fenestrate Exposed Bone to Stimulate Wound Healing. Dermatologic Surgery, 17, 265-270. https://doi.org/10.1111/j.1524-4725.1991.tb03641.x

[8] Koenen, W., Goerdt, S. and Faulhaber, J. (2008) Removal of the Outer Table of the Skull for Reconstruction of Full-Thickness Scalp Defects with a Dermal Regeneration Template. Dermatologic Surgery, 34, 357-363.

[9] Greaves, N.S., Ashcroft, K.J., Baguneid, M. and Bayat, A. (2013) Current Understanding of Molecular and Cellular Mechanisms in Fibroplasia and Angiogenesis during Acute Wound Healing. Journal of Dermatological Science, 72, 206-217. https://doi.org/10.1016/j.jdermsci.2013.07.008

[10] Stadelmann, W.K., Digenis, A.G. and Tobin, G.R. (1998) Physiology and Healing Dynamics of Chronic Cutaneous Wounds. American Journal of Surgery, 176, 26S-38S.

[11] Bianco, P., Riminucci, M., Gronthos, S. and Robey, P.G. (2001) Bone Marrow Stromal Stem Cells, Nature, Biology, and Potential Applications. Stem Cells, 19, 180-192. https://doi.org/10.1634/stemcells.19-3-180

[12] Parlier-Cuau, C., et al. (2013) Diagnostic d'une lacune de la voûte du crâne. Revue du Rhumatisme Monographies, 80, 44-57.

[13] Carter, D.R., Beaupre, G.S., Giori, N.J. and Helms, J.A. (1998) Mechanobiology of Skeletal Regeneration. Clinical Orthopaedics and Related Research, 355, S41-S55.

[14] Gardner, T.N., Stoll, T., Marks, L., Mishra, S. and Tate, M.K. (2000) The Influence of Mechanical Stimulus on the Pattern of Tissue Differentiation in a Long Bone Fracture-An FEM Study. Journal of Biomechanics, 33, 415-425. https://doi.org/10.1016/S0021-9290(99)00189-X

[15] Lacroix, D. and Prendergast, P.J. (2002) A Mechano-Regulation Model for Tissue Differentiation during Fracture Healing: Analysis of Gap Size and Loading. Journal of Biomechanics, 35, 1163-1171. https://doi.org/10.1016/S0021-9290(02)00086-6 
[16] Desmoulière, A., Chaponnier, C. and Gabbiani, G. (2005) Tissue Repair, Contraction, and the Myofibroblast. Wound Repair and Regeneration, 13, 7-12. https://doi.org/10.1111/j.1067-1927.2005.130102.x

[17] Rossio-Pasquier, P., Casanova, D., Jomard, A. and Démarchez, M. (1999) Wound Healing of Human Skin Transplanted onto the Nude Mouse after a Superficial Excisional Injury: Human Dermal Reconstruction Is Achieved in Several Steps by Two Different Fibroblast Subpopulations. Archives of Dermatological Research, 291, 591-599. https://doi.org/10.1007/s004030050460

[18] Tomasek, J.J., Gabbiani, G., Hinz, B., Chaponnier, C. and Brown, R.A. (2002) Myofibroblasts and Mechano-Regulation of Connective Tissue Remodelling. Nature Reviews Molecular Cell Biology, 3, 349-363. https://doi.org/10.1038/nrm809

[19] Snow, S.N., Stiff, M.A., Bullen, R., et al. (1994) Second-Intention Healing of Exposed Facial-Scalp Bone after Mohs Surgery for Skin Cancer: Review of Ninety-One Cases. Journal of the American Academy of Dermatology, 31, 450-454. https://doi.org/10.1016/S0190-9622(94)70209-8

[20] Mitchell, G.F. (1933) Total Avulsion of the Scalp. A New Method of Restauration. British Medical Journal, 7, 13-16. https://doi.org/10.1136/bmj.1.3757.13

[21] Pitkanen, J.M., Al-Qattan, M.M. and Russel, N.A. (2000) Immediate Coverage of Exposed, Denuded Cranial Bone with Split-Thickness Skin Grafts. Annals of Plastic Surgery, 45, 118-121. https://doi.org/10.1097/00000637-200045020-00003

[22] Furlanetti, L.L., de Oliveira, R.S., Santos, M.V., Farina Jr., J.A. and Machado, H.R. (2010) Multiple Cranial Burr Holes as an Alternative Treatment for Total Scalp Avulsion. Child s Nervous System, 26, 745-749.

https://doi.org/10.1007/s00381-010-1145-7 